Barnabé, MIDEO 6 (1959-61), 137-226; Tijana Krstić, Los Moriscos en Estambul, in Mercedes García-Arenal and Gerard Wiegers (eds.), Los Moriscos. Expulsión y diáspora. Una perspectiva internacional (Valencia 2013), 257-73; Pieter Sjoerd van Koningsveld, The Islamic image of Paul and the origin of the Gospel of Barnabas, FSAI 20 (1996), 200-21; Martin Mulsow, Socinianism, Islam and the radical uses of Arabic scholarship, $A l-$ Qantara, 31/2 (2010), 549-86; Umar Ryad, Islamic reformism and Christianity. A critical reading of the works of Muhammad Rashìd Ridā and his associates (1898-1935), Leiden 2009; Jan Slomp, The Gospel of Barnabas in recent research, Islamochristiana 23 (1997), 81-109; Christine Schirrmacher, Mit den Waffen des Gegners. Christlich-muslimische Kontroversen im 19. And 20. Fahrhundert dargestellt am Beispiel der Auseinandersetzung um Karl Gottlieb Pfanders "Mìzân al-haqq" und Rahmatullâh ibn $\underline{\text { Halìl }}$ al-'Uthmânî al-Kairânawîs "Izhâr al-haqq" und der Diskussion über das Barnabasevangelium, Berlin 1992; Ryan Szpiech, Preaching Paul to the Moriscos. The Confusión o confutación de la secta mahomética y del Alcorán (1515) of Juan Andrés, La Corónica 41/1 (2012), 317-43; Gerard Wiegers, Muhammad as the Messiah. A comparison of the polemical works of Juan Alonso with the Gospel of Barnabas, BO 52/3-4 (1995), 245-91.

Gerard Wiegers

\section{Gratitude (shukr) and ingratitude}

Gratitude, shukr or shukür, according to Muslim authors, is an attribute of God and of the virtuous person, which entails recognising and openly appreciating any benefit received; moreover, it deals with scarcity repaid with abundance, with increase and multiplication, and in this sense the only Absolutely Grateful One is God. Being grateful towards God is an essential ingredient of faith; it follows that its opposite, ingratitude, or kufrān, implies faithlessness, or kufr. Furthermore, gratitude is to be understood as not only a religious duty but also a social one, insofar as a well-known Prophetic saying links ingratitude towards one's fellow human beings with ingratitude towards God.

\section{Gratitude, an attribute}

OF GOD AND OF THE VIRTUOUS

\section{PERSON}

"The Exceedingly Grateful" (shakür) is among the so-called Most Beautiful Names of God; it traces back to the Qur'ān. Some writers (among them al-Hākim al-Nisābūrī, d. 405/1014) include among the Names shākir, "The Grateful," which too appears in the Qur'ān (Q 2:158, 4:147). At the same time, both terms are also attributes of pious believers (shakūr: Q 14:5, 17:3, 31:31, 34:19, 42:33; shākir: 16:121, 76:3) and therefore, following the reasoning set forth by al-Ghazālī (d. 555/1111) in al-Maqsad, can be referred to as "shared" (mushtaraka) or "equivalent" (mutashābiha) Names (al-Ghazālī, 47-59).

According to Ibn Manẓūr (d. 711/ 1311-2), gratitude, or shukr, with its synonym shukurr, is recognition and open appreciation of a benefit received, with words, actions, and intentions, as well as singing the praises (hamd, than $\bar{a}^{\prime}$ ) of the originator of the good deed (mun im). This author insists on the material aspect of gratitude, either God's or man's: shukr derives from the expression shakarat al-ibil, applied to "camels that fatten at pasture," and therefore it deals with scarcity repaid with abundance, with increase (ziy $\bar{a} d a)$ and multiplication (mudāa afa) (Lisān, 4:423-7).

On increase as a necessary ingredient of gratitude, al-Ghazālī writes that "the only Absolutely Grateful One (shakür mutlaq) is God; in fact, that which He adds is without limit, because there is nothing beyond the beatitude of paradise" (Maqsad, 114). The great theologian makes clear the interconnection between the divine and 
the human inherent in shukr and notes that God's praise, although directed towards the actions of His servants, is nonetheless returned to Himself, in that human actions are created by Him and humankind's gratitude towards God also derives from Himself, for $\mathrm{He}$ is the only One to sanction it. Similar are the reflections of Ibn Qayyim al-Jawziyya (d. 751/1350) in 'Uddat al-säbirin ("The tools of the patient ones"). This Hanbalī scholar teaches that God too is grateful to the obedient servant, as the servant is to Him, and that "God is the Grateful and loves those who are grateful" (Ibn Qayyim, 282-3).

\section{Gratitude as a religious} AND SOGIAL DUTY

As Ibn Ab̄i al-Dunyā (d. 281/894) points out in a well-known work of traditional content titled al-Shukr li-llāh ("Gratitude towards God"), shukr means to declare "praise be to God" on every occasion, because everything is grace (food and drink, new clothes, the body that has been given to the person, his or her very breath, and so forth, and even the human capacity for being grateful) and because, as the wise person knows, grace may lie as much in what does not go ill for him as in what goes well (Ibn Abī al-Dunyā, passim). In this book there also appear occasional references to patience (s $(s b r)$ : according to a Prophetic saying: "He who is afflicted must show patience, he who receives a gift must show gratitude" (65-6). A certain apotropaic efficacy is also associated with gratitude: "grace is shackled with the instrument of gratitude" (19). Among the exemplary figures cited by Ibn Abī al-Dunyā are Moses (cf. Q 34:13) and David (cf. Q 7:144. Worth remembering is the relationship linking David to the "prostration in thankfulness," sajdat or sujūd al-shukr, to be performed, fol- lowing the Prophet's example, on every instance of receiving good news.) This author reports as well a Prophetic saying, lā yashkuru Allāh man lā yashkuru al-nās (Ibn Abī al-Dunyā, 31; Abū Dāwud; Reinhart, Thanking, 119), that is, "he who is not grateful to others is not grateful to God" or, quite differently, "God is not grateful to him who is not grateful to others."

This maxim is quoted by al-Kharā'iți (d. 327/939) in Fadīlat al-shukr ("The excellence of gratitude"), followed by Ibn Muflih (d. 763/1361) in al-Ādāb al-shar'iyya ("The lawful customs"). These authors incline to an entirely human interpretation of the saying and inaugurate a discussion of gratitude as a social duty: precisely because it is an attribute of God, shukr should be an attribute of the virtuous person, towards God and also towards fellow human beings, in so far as what the believer owes to God, he or she owes also, mutatis mutandis, to fellow human benefactors (al-Kharā’ițī, 61-71; Ibn Muflih, 1:330-5).

\section{Ingratitude to God and \\ TO PEOPLE AS A SYNONYM OF UNBELIEF}

When Ibn Manẓūr writes that "gratitude is the opposite of ingratitude (kufrān)," he mirrors the similar contrast of gratitude and unbelief (kufr) that occurs several times in the Qur'ān (for example, "if anyone is grateful, it is for his own good, if anyone is ungrateful [or "unbelieving," man kafara], then my Lord is sufficient unto Himself" Q 27:40) and recalls an amplified version of the Prophetic saying just quoted - lā yashkuru Allāh man lā yashkuru al-nās - reported many times over in Ibn Hanbal's (d. 241/855) Musnad, which begins in this way: "To speak of benefits received means to be grateful, and to pass over them in silence signifies impiety 
(kufr); he who is not grateful for little is not grateful for much." Thus, overlooking benefits received and being unthankful become a common way of indicating faithlessness towards God.

Nevertheless, ingratitude - a disposition of the soul which may equally be generated in humankind by the arrival of ill fortune after good or after the arrival of good after ill (Zilio-Grandi, 33-4) - is part and parcel of human nature, as many passages of the Qur'ān dealing with humankind in general (al-insān) seem to assert. But according to a number of authoritative commentators (among them, al-Ṭabarī, d. 310/923, and al-Rāzī, d. 606/1209), in these cases it is merely a question of those who are distinguished by their propensity for remembering only their afflictions and forgetting favours received.

Another Qur'ānic expression indicating the person who is ungrateful to God is kanüd (Q 100:6), which denotes someone who breaks the bond with divine favour in the manner of a son who repudiates his father, with possible reference to the name of the ancient Arab tribe the Kinda (Ibn Manz̄ūr, 3:382).

The same concomitance of ingratitude and impiety resurfaces in al-Kharā'ițî̀'s work on the subject of man's behaviour towards his brother; for example, from the Prophet: "There are servants to whom, on the day of the resurrection, God will not speak...they are those who deny their parents... those who deny their own sons, and those who receive help from others and repudiate (kafara) that help and disown them" (al-Kharā'ițī, 70; cf. Ibn Muflih, 333). In the same work there also appears a no less relevant form of human ingratitude to the benefactor (kufr al-mun'im), which is that of the wife towards her husband, in a parable recounted by Asmā’ bt. Yazīd b. al-Sakan (d. 30/650-1), the celebrated "preacher of the women" (al-Kharā'ițī, 71).

\section{BIBLIOGRAPHY}

Sources

Abū Dāwūd, Sunan, kitāb al-adab, bāb fì shukr al-ma'rūf; al-Ghazālī, al-Maqșad al-asnā fì Sharh ma'ān̄̄ asmā' Allāh al-ḥusnā, ed. Fadlou Shehadi, Beirut 1971; al-Ṭabarī, Jāmi al-bayān, 30 vols., Beirut 1412/1992, facsimile repr. of $1323 \mathrm{H}^{1}$; Ibn Manzūr, Lisān al-'Arab (Beirut 1410/1990), 4:423-7; Ibn Muflih al-Muqaddasī, al-Ādāb al-shar îyya, ed. Shu'ayb al-Arna'ūt and 'Umar al-Qayyān, 3 vols., Beirut 1419/1999; Ibn Qayyim al-Jawziyya, 'Uddat al-șābirinn wa-dhakhīrat al-shākirīn, ed. Zakariyā 'Al̄̄ Yūsuf, Beirut n.d.; Ibn Ab̄̄ al-Dunyā, al-Shukr li-llāh, ed. Muhammad Basyūn̄̄ Zaghlūl, Beirut 1413/1994; Abū Bakr al-Kharāị̀̄i, Fadīlat al-shukr li-llāh 'alā ni'mati-hi wa-mā yajibu min al-shukr li-l-mun'im 'alay-hi wa-mā fì dhālika min al-thawāab, ed. Muhammad Muțī al-Hāfiz, Damascus 1402/1982; Fakhr al-Dīn al-Rāzī, Mafātīh al-ghayb, 11 vols., Beirut 1415/1995.

STUdies

Mahmoud Ayoub, Thanksgiving and praise in the Qur'ān and in Muslim piety, Islamochristiana 15 (1989), 1-10; Alma Giese, Shukr, 1. As a religious and mystical concept, EI2; Daniel Gimaret, Les noms divins en Islam. Exégèse lexicographique et théologique (Paris 1988), 420-2; Léonard Librande, Ibn Abī al-Dunyā. Certainty and morality, SI 100/101 (2005), 5-42; A. Kevin Reinhart, Shukr, 2. As a factor in public life and in the principles of law, EI2; A. Kevin Reinhart, Thanking the benefactor, in John B. Carman and Frederick J. Streng (eds.), Spoken and unspoken thanks. Some comparative soundings (Cambridge MA and Dallas 1999), 115-33; Lamin Sanneh, Gratitude and ingratitude, EQ; Roberto Tottoli, The thanksgiving prostration (sujüd al-shukr) in Muslim traditions, BSOAS 61/2 (1998), 309-13; Ida Zilio-Grandi, The gratitude of man and the gratitude of God. Notes on šukr in traditional islamic thought, Islamochristiana 38 (2012), 45-61; Ida Zilio-Grandi, Il Corano e il male, Turin 2002.

IDA ZILIO-GRANDI 